\title{
Teoretyczny rozdział kompetencji pomiędzy dawnymi medykami i chirurgami a codzienna praktyka lecznicza opisana w egodokumentach staropolskich
}

\section{Theoretical Division of Competences Between Physicians and Surgeons, and the Daily Medical Practice Described in Old-Polish Egodocuments}

It is predominantly accepted in the historiography of European medicine that, apart from the differences in education, there was a division of competences between physicians educated at universities and barber-surgeons trained in the guild system in terms of their theoretical background. Regardless of the former stereotypes - dating back to the $19^{\text {th }}$ century - relating to the Church-imposed restrictions in teaching surgery at universities, it is believed that the actual differences in terms of competences must have influenced the scope of the undertaken therapeutic activities. A different education model and the predominance of either theoretical or practical knowledge among representatives of these groups resulted in different treatment methods and a different perception of the causes of the disease. Physicians with mainly theoretical knowledge are often put in opposition to practising barber-surgeons. While it seems that the reluctance to bloody operations (sometimes articulated by the surgeons themselves) was a reason for the limited involvement of physicians in the barber-surgeon practice, it is difficult to clearly indicate the factors that would prevent surgeons from dealing with "non-operational" treatment. The article attempts to answer the question to what extent the then-existing differences in education and legal restrictions influenced the actual division of therapeutic tasks and the functioning of various medical professions as viewed from the patient's perspective.

Keywords: history of medicine, Old-Polish memoirs, egodocuments, $16^{\text {th }}-17^{\text {th }}$ centuries Słowa kluczowe: historia medycyny, pamiętniki staropolskie, egodokumenty, XVI-XVII wiek

Znaczenie i waga posiadania zarówno wiedzy teoretycznej, jak i kompetencji praktycznych w celu zapewnienia prawidłowej opieki zdrowotnej są dziś niepodważalnym faktem. Spór o to, które z nich są ważniejsze i w jakich proporcjach powinny być łączone, bynaj- 
mniej nie wygasł i stanowi istotny czynnik, np. podczas ustalania programu kształcenia przedmiotów medycznych szkół wyższych. W epoce nowożytnej kwestie prymatu teorii lub praktyki w lecznictwie miały fundamentalne znaczenie, gdyż funkcjonował oparty na tej podstawie podział w nauczaniu i uprawianiu medycyny. Charakter oraz zakres tego rozdzielenia są już od dawna przedmiotem badań historyków, stąd w początkowej części pracy jedynie podsumuję jego genezę i funkcjonowanie. Artykuł jest próbą odpowiedzi na pytanie, na ile istniejące wówczas różnice w sposobie kształcenia oraz ograniczenia prawne (wynikające m.in. z ustawodawstwa cechowego) wpływały na realny podział zadań terapeutycznych oraz funkcjonowanie różnych zawodów medycznych w oczach pacjenta z terenów Rzeczypospolitej Obojga Narodów.

Tematem prowadzonych dociekań będzie nie tyle sam podział medycyny, co jego wpływ na realną praktykę leczniczą, której odbicie znaleźć można w egodokumentach¹ epoki staropolskiej². Wybrana baza źródłowa stanowiła dotąd podstawę dla rozważań na temat mentalności staropolskiej w zakresie postrzegania zdrowia i choroby. Oprócz analizy mentalności egodokumenty stanowią też dobre źródło do badań właśnie rzeczywistych, a nie jedynie deklaratywnych zachowań społecznych, ponieważ przedstawiają „mimowolne" świadectwo ówczesnej rzeczywistości³. Opisy czynności prozaicznych, w odniesieniu do których autor nie podejrzewał, że mogłyby stać się podstawą oceny jego osoby, mają większą szansę przedstawić realny i niezafałszowany obraz działań i poglądów. Ponadto dzienniki i osobista korespondencja stosunkowo często przełamują zamkniętą w innych rodzajach źródeł „pułapkę codzienności”, gdyż poświęcają uwagę także sprawom błahym i dla ówczesnych oczywistym, a także osobistym ocenom opisywanych wydarzeń ${ }^{4}$.

Analizowane zagadnienie realnego funkcjonowania rozdziału kompetencji w lecznictwie może być oparte o świadectwa grupy korzystającej z ówczesnej profesjonalnej pomocy medycznej. Grupa ta składa się z przedstawicieli różnych warstw społecznych, których cechą wspólną jest wystarczający poziom zamożności oraz świadomości zdrowotnej ${ }^{5}$. Ustalenie pewnej standaryzacji lub ujednolicenia w omawianej grupie nie jest możliwe, gdyż autorzy stanowią zbyt różnorodny konglomerat, stąd nie może być mowy o ustaleniu podstawowego modelu zachowania i poglądów dla społeczeństwa staropolskiego ${ }^{6}$. Kwestią podstawową w prowadzonych badaniach nie jest jednak zdefiniowanie spójnej grupy, dla której udałoby się wypracować wspólny model, lecz ogólna skąpość źródeł poruszających kwestie lecznictwa w jego rzeczywistym, a nie jedynie normatywnym kształcie. Wymaga to odwoływania się do szerokiego materiału źródłowego, co z kolei rodzi problem jego niejedno-

1 Definicja i określenie pojęcia egodokumentów (lub ego-dokumentów) zostały już w historiografii ustalone, zob. W. Szulakiewicz, Ego-dokumenty i ich znaczenie w badaniach naukowych, „Przegląd Badań Edukacyjnych" t. 1 (16), 2013, s. 65-84.

2 W trakcie badań autor wykorzystywał wydane drukiem staropolskie zbiory korespondencji, pamiętniki i diariusze oraz wybrane rękopisy o charakterze prywatnych zapisek, pochodzące z XVI-XVIII wieku. Por. J. Węglorz, Zdrowie, choroba i lecznictwo w społeczeństwie Rzeczypospolitej XVI-XVIII wieku, Toruń 2015, s. 35-50.

3 D. Bąkowski-Kois, Historia mentalności epoki nowożytnej. Jeszcze o problemach, „Historyka. Studia Metodologiczne" t. 31, 2001, s. 97.

4 D. Rolnik, Portret szlachty czasów stanisławowskich, epoki kryzysu, odrodzenia i upadku Rzeczypospolitej w pamiętnikach polskich, Katowice 2009, s. 36-37.

5 Pomijając ewentualne kontrowersje dotyczące definicji istoty "grupy", roboczo przyjmuje się wykładnię przytoczoną przez Dariusza Bąkowskiego-Koisa, op. cit., s. 97

6 Określenie „model” rozumie się tu zgodnie z podejściem prezentowanym przez Jerzego Topolskiego, Teoria wiedzy historycznej, Poznań 1983, s. 251-277. 
rodności. W przypadku prowadzonych rozważań nie stanowi jednak o jego dyskwalifikacji, analizowana bowiem nie jest całość zachowań, podglądów czy mentalności autorów źródeł, lecz jedynie ich stosunek do lecznictwa oraz ich postrzeganie realnego kształtu tegoż. Wskazanie na funkcjonowanie pewnych schematów zachowań i współwystępowanie podobnych poglądów daje możliwość wyciągnięcia wniosków i zauważanie prawidłowości, nawet w sytuacji, gdy w warstwie ogólnej badana grupa jednorodna nie jest.

W tekście zastosowano nazewnictwo profesji medycznych zgodne z praktykowanymi w okresie staropolskim zwyczajami: termin „lekarz” używany jest na określenie każdego przedstawiciela społeczności podejmującego się prowadzenia terapii. Słowem "medyk" lub „doktor” (łac. medicus lub doctus) określany jest człowiek, który ukończył uniwersyteckie studia medyczne (lub głosił takie twierdzenie, niezależnie od stanu faktycznego), z kolei „cyrulik”, „felczer”, „balwierz” i „aptekarz” to przedstawiciele zawodów funkcjonujących $w$ systemie cechowym ${ }^{7}$. Próby ustalenia zakresu funkcjonowania $w$ praktyce formalnego podziału lecznictwa i rozgraniczenia działań terapeutycznych zgodnie z monopolami korporacyjnymi utrudnia fakt, że w wielu przypadkach egodokumenty nie specyfikują, o jakiego przedstawiciela dawnych zawodów medycznych chodzi w konkretnej sytuacji. Czasem zaś opisy są niejednoznaczne, a używane nazewnictwo określające ludzi parających się lecznictwem pozostawia bardzo szerokie pole do interpretacji. W Rzeczypospolitej nie było skutecznego systemu kontroli uprawnień do leczenia, a pacjenci w niewielkim stopniu wykazywali zainteresowanie tytułami naukowymi prezentowanymi przez terapeutę ${ }^{8}$ Kluczowe znaczenie miała opinia wyleczonych pacjentów, którzy rekomendowali danego lekarza. Chorzy niewielką wagę przykładali do formalnych kwalifikacji i nieraz zdarzało się, że nawet empirycy i szarlatani, którzy mieli jedynie podstawową wiedzę medyczną, tytułowali się doktorami (najczęściej sławnymi). Zwykle nie wzbudzało to sprzeciwu pacjentów, nie zawsze potrafiących zresztą zauważyć różnicę?.

W czasach starożytnych regulacje dotyczące nauczania i wykonywania zawodu lekarza nie były w pełni ustalone i sformalizowane. Choć występowały różne "szkoły" medyczne, stanowiły one raczej skupioną wokół mistrza grupę uczniów niż ośrodki o usystematyzowanej strukturze ${ }^{10}$. Już od $V$ w. p.n.e. zauważalne jest jednak rosnące napięcie między ideą zdobywania umiejętności przez praktykę a koncepcją lekarza jako filozofa ${ }^{11}$. W okresie wczesnego średniowiecza kwestie uprawnień do leczenia i formalnego podziału kompetencji terapeutów pozostawały zupełnie na uboczu. Spadkobiercami antycznej tradycji medycyny religijnej, ale i depozytariuszem znacznej wiedzy pozostawały klasztory z ich zbiorami bibliotecznymi. Ponadto, przynajmniej w niektórych ośrodkach klasztornych, lecznictwo (nie tylko w postaci ziołolecznictwa) było realnie praktykowane ${ }^{12}$. Między $\mathrm{V}$ a X w. doszło do wykształcenia się kilku bardzo wpływowych ośrodków nauczania me-

7 Szerzej o dawnym nazewnictwie zawodów medycznych: J. Węglorz, op. cit., s. 50-52.

8 Zagadnienie podejścia do formalnych kwalifikacji terapeuty i ich ewentualnego weryfikowania było już przez autora opracowywane: J. Węglorz, Znaczenie i postrzeganie kwalifikacji do uprawiania sztuki lekarskiej w Rzeczypospolitej, [w:] Sapientia ars vivendi putanda est. Wokót kultury i polityki. Studia z dziejów nowożytnych ofiarowane Profesorowi Marianowi Chachajowi, red. A. Perłakowski, B. Rok, F. Wolański, Kraków 2019, s. 47-60.

9 Ibid., s. 52.

10 T. Gelfand, The History of the Medical Profession, [w:] Companion Encyclopedia of the History of Medicine, red. W.F. Bynum, R. Porter, t. 2, London - New York 1993, s 1119-1120.

11 S. Lawrence, Medical Education, [w:] Companion Encyclopedia, s. 1155-1156.

12 L. Ghislaine, Surgey (traditional), [w:] Companion Encyclopedia, s. 961-983. 
dycyny - przede wszystkim w Bagdadzie, w Konstantynopolu oraz w Salerno. Co charakterystyczne, ośrodki te początkowo swą reputację zawdzięczały grupie lekarzy „praktyków” zajmujących się leczeniem i szkoleniem uczniów, dopiero później przeradzały się w centra wiedzy i edukacji skupiające się w rosnącym stopniu na jej teoretycznym przekazywaniu ${ }^{13}$. Jest to o tyle istotne, że wskazuje na płynną wówczas granicę między teorią a praktyką medyczną i brak istnienia realnych podziałów w tym zakresie.

Najstarsze znane przepisy regulujące kwestie uprawnień do praktykowania działalności medycznej w średniowiecznej Europie pochodzą dopiero z XII i XIII w. W 1140 r. Roger II, król Sycylii, Kalabrii i Apulii, wydał edykt wprowadzający nakaz uzyskania aprobaty ośrodka w Salerno przed rozpoczęciem praktyki lekarskiej w królestwie ${ }^{14}$. W podobnym duchu brzmiało wprowadzone w 1231 r. przez cesarza Fryderyka II Hohenstaufa prawo zezwalające na praktykę lekarską wyłącznie osobom, które uprzednio zdały w Salerno egzamin połączony z publiczną dysputą ${ }^{15}$. W tym samym okresie dochodziło też do powstawania pierwszych aptek oraz organizacji cechowych skupiających praktyków wykonujących zawody medyczne. Najstarsze europejskie apteki pochodzą z XIII w. ${ }^{16}$, choć już w XII w. pojawiały się wzmianki o istnieniu cechu handlarzy ziołami (aromatarii lub confectionarii) oraz pierwszych kramach oferujących także rośliny lecznicze ${ }^{17}$. Także w XIII w. w miastach europejskich licznie występują już cechy balwierzy, które w tamtym okresie zrzeszały również chirurgów $^{18}$. Rolą cechów aptekarzy i balwierzy (jak i wszystkich organizacji cechowych) była zarówno ochrona klientów przed nieuczciwymi cenami czy słabą jakością produktów, jak też zapewnienie członkom cechu monopolu gwarantującego ustalone ceny i ochronę przed konkurencją ${ }^{19}$. W połowie XIII w. we Francji doszło do wyodrębnienia się bractwa św. Kosmy i Damiana z cechu balwierzy, co stanowiło widomy znak funkcjonowania nauczania i praktyki chirurgicznej jako osobnej od medycyny specjalności².

Pierwsze uniwersytety pojawiły się w Europie już w XI w., ale ich rosnący wpływ na życie naukowe datowany jest dopiero od XII w. Wraz z rozpowszechnianiem się w XIII w. miejskich cechów regulujących kwestię prawa do uprawiania wybranych praktyk lekarskich (m.in. zabiegów chirurgicznych) czynniki te spowodowały wyłanianie się zarówno formalnych zasad, jak i umownych ograniczeń w kwestii uprawnień do wykonywania zawodów lekarskich ${ }^{21}$. Prawo cechowe zezwalało na wykonywanie usług podlegających

13 S. Lawrence, op. cit., s 1156-1157.

14 J. Jagla, Boska medycyna i niebiescy uzdrowiciele wobec kalectwa i chorób człowieka, Warszawa 2004, s. 22-23.

15 T. Brzeziński, Kształtowanie się zawodu lekarza i koncepcje kształcenia, [w:] Historia medycyny, red. idem, Warszawa 1988, s. 65-67.

16 Jedne z najstarszych aptek wzmiankowane są w Wetzlar w 1233 r., w Świdnicy w 1248, czy w Wurzburgu w 1276 r. W XV w. apteki funkcjonowały już nie tylko we wszystkich największych miastach, lecz nawet w drugorzędnych ośrodkach miejskich: zob. T. Puschmann, A History of Medical Education. From the Most Remote to the Most Recent Times, tłum. i red. E.H. Hare, London 1891, s. 253.

17 R. Rembieliński, B. Kuźnicka, Historia farmacji, Warszawa 1972, s. 175-178.

18 L. Ghislaine, op. cit., s. 969-970.

19 J. Burnby, An Examined and Free Apothecary, [w:] The History of Medical Education in Britain, red. V. Nutton, R. Porter, Amsterdam - Atlanta 1995, s. 16.

20 F. Lebrun, Jak dawniej leczono. Lekarze, święci i czarodzieje w XVII i XVIII wieku, tłum. Z. Podgórska-Klawe, Warszawa 1997, s. 39.

21 Wykonywanie operacji chirurgicznych, takich jak amputacje, usuwanie zaćmy, ale i drobniejszych zabiegów w rodzaju zszywania rany, nastawiania złamań czy też przecinania wrzodów, było zgodnie z prawem cechowym zarezerwowane dla członków cechu. Pewne kontrowersje istniały wokół zabiegu upuszczania krwi: S. Lawrence, op. cit., s 1154-1155. 
kontroli cechu jedynie członkom lokalnego bractwa. W ogólnym założeniu wszelkie zabiegi manualne, takie jak np. nastawianie złamań, szycie ran, amputacje, usuwanie zaćmy czy wypalanie wrzodów, były przedmiotem monopolu cechu cyrulików i balwierzy, z kolei przygotowywanie leków i ich sprzedaż kontrolował cech aptekarzy. W zależności od kraju i okresu zasięg monopolu cechowego ulegał pewnym wahaniom i niektóre kwestie, jak m.in. prawo do wykonywania upustów krwi przez lekarzy czy podawania lewatyw i udzielania porad medycznych przez aptekarzy, było przedmiotem sporów pomiędzy konkurującymi korporacjami ${ }^{22}$. Sprawą odrębną, podlegającą nadal badaniom i dyskusji, jest zakres egzekwowania tych ograniczeń i respektowania ustaleń przez uniwersyteckich medyków. Warto zaznaczyć, że w XIII i XIV w. w nauczaniu świeckich uniwersytetów włoskich pomimo funkcjonowania już formalnych rozgraniczeń (m.in. prawa cechowego) prowadzone były zajęcia z chirurgii, a także lekcje anatomii, częstokroć też dawano studentom możliwość obserwacji pacjentów w szpitalach ${ }^{23}$. Trudno jednak określić jednoznacznie, czy te elementy „praktyki” miały przygotować do faktycznego uprawiania terapii zabiegowej, czy też dawać szerszą wiedzę i kontekst niezbędny w celu skutecznego stosowania lecznictwa humoralnego (nieinwazyjnego).

Przypisywany nauczaniu Kościoła przymusowy rozdział chirurgii od medycyny i rzekomy zakaz wykonywania zabiegów chirurgicznych przez medyków nie daje się obronić w świetle ustaleń historiografii. Przywoływany nieraz zakaz przelewania krwi i uczestnictwa w krwawych turniejach dotyczył jedynie wyższego duchowieństwa i miał na celu względy prestiżowe, powtarzane zaś od dwóch stuleci stwierdzenie ecclesia abhorret a sanguine, ustanowione rzekomo podczas synodu w Tours z 1163 r., nie znajduje się w żadnych tekstach ustaleń synodalnych i przytaczany jest po raz pierwszy dopiero w 1744 r. ${ }^{24}$ Uniwersytety faktycznie stopniowo ograniczały swoje zaangażowanie w stosowanie i nauczanie chirurgii, miało to jednak miejsce dopiero w późniejszym okresie. Wynikało przy tym ze złożonych przyczyn i nie było prostą konsekwencją odgórnie ustalonego zakazu.

W omawianym okresie status społeczny chirurga-balwierza był znacznie niższy niż wykształconego na uniwersytecie medyka, ale przynajmniej do końca XIV w. w nauczaniu medycyny nie daje się zauważyć jednoznacznego odrzucenia chirurgii jako nielicującej z powagą zawodu²5. Jak już wspomniano, rzeczywista skala i realia praktykowania zabiegów chirurgicznych przez medyków i wykładowców uniwersyteckich pozostają trudne do określenia. Na przestrzeni XIII i XIV w. powstawały prace naukowe pisane przez wykształconych na uniwersytecie lekarzy (m.in. Guy de Chauliac), które dotyczyły chirurgii, a nawet opisywały dokładnie przebieg skomplikowanych i innowacyjnych operacji. Jednak sposób opisu i kontekst świadczą, że autorzy osobiście tego rodzaju zabiegów nie przeprowadzali ${ }^{26}$. Tendencje do odchodzenia uniwersyteckich medyków od stosowania w praktyce zabiegów chirurgicznych odnosić należy raczej do okresu nowożytnego, nie były one przy tym regułą, a jedynie generalnym trendem. W całym omawianym okresie nauczanie anatomii i prezentowanie sekcji było stałym elementem edukacji uniwersytec-

22 T. Gelfand, op. cit., s 1122-1126; F. Lebrun, op. cit., s. 66-67.

23 T. Gelfand, op. cit., s 1123-1124; S. Lawrence, op. cit., s 1157-1159.

24 Ch.H. Talbot, Medicine in Medieval England, London 1976, s. 55.

25 L. Ghislaine, op. cit., s. 969.

26 Ibid., s. 968. 
kiej. Na uniwersytetach włoskich w XVI w. wykładowcy medycyny często i chętnie odwoływali się do praktycznych obserwacji dokonywanych zarówno podczas terapii chorych, jak i sekcji zwłok. Służyło to jednak przeważnie uzasadnieniu i potwierdzeniu twierdzeń budowanych w oparciu o teksty antycznych mistrzów ${ }^{27}$. Wykonywanie sekcji czy obserwacja prowadzonych operacji chirurgicznych (przeważnie rękami cechowych cyrulików) w XVI i XVII w. w uniwersyteckich teatrach anatomicznych także stanowiły przede wszystkim ilustrację naukowej debaty i pomoc w edukacji. Eksperymenty na zwierzętach, sekcje, prezentacje chirurgiczne miały zazwyczaj stanowić dowody tez opracowanych w toku teoretycznych rozważań (czasem też unaocznić studentom słuszność głoszonych poglądów), a nie służyć nauczaniu praktycznych umiejętności ${ }^{28}$.

Podziały prawne i formalne regulujące prawo do wykonywania profesji medycznych w okresie nowożytnym przybierały odmienne formy i cechowały się zróżnicowaną intensywnością. Zauważalna w XV i XVI w. dominacja medyków uniwersyteckich nad pozostałymi profesjami medycznymi wyrażała się zarówno większym prestiżem i statusem majątkowym, jak też częściową kontrolą nadawania stopni i oficjalnych funkcji sprawowanych przez chirurgów i aptekarzy. Wobec rosnących kwalifikacji i ambicji niektórych przedstawicieli tych profesji, ograniczanych zarówno przez rzemieślniczy charakter organizacji cechowych, jak i często niechętny im stosunek elit uniwersyteckich, rozpoczął się powolny proces emancypacji chirurgii i aptekarstwa jako odrębnych zawodów oraz dyscyplin naukowych. W XVII w. w niektórych krajach dochodziło do zmian stosunków prawnych i wydzielenia się wysoko wykwalifikowanych chirurgów z cechu balwierzy, a aptekarzy z cechu handlarzy korzennych ${ }^{29}$. We Francji konflikt między wybijającym się na samodzielność bractwem św. Kosmy, które nauczało chirurgii, pretendując przy tym do nadawania stopni i prezentowania rozpraw naukowych, oparł się w połowie XVII w. o parlament Paryża. Wobec oporu uniwersyteckich lekarzy wcielono chirurgów do cechu balwierzy, ucinając ich ambicje oraz zakazując noszenia togi i biretu ${ }^{30}$. Specyfika tego sporu, podobnie jak rozgrywającego się w Anglii procesu Wiliama Rosa ${ }^{31}$ czy konfliktu między cechem chirurgów a kolegium medycznym w Stuttgarcie ${ }^{32}$, wskazuje raczej na ekonomiczno-korporacyjny charakter podziału ówczesnego lecznictwa. Dopiero w okresie XVIII w. dochodzi do stopniowego przełamania trwającego konfliktu poprzez podniesienie nauczania chirurgii i aptekarstwa do rangi przedmiotów uniwersyteckich ${ }^{33}$. Warto jednak pamiętać, że proces ten, choć zapoczątkowany w Paryżu i Londynie jeszcze w pierwszej połowie

27 A. Wear, Explorations in Renaissance Writings on the Practice of Medicine, [w:] The Medical Renaissance of the Sixteenth Century, red. A. Wear, R.K. French, I.M. Lonie, Cambridge 1985, s. 135-141.

28 L. Ghislaine, op. cit., s. 971-972.

29 W Anglii w 1618 r. usamodzielnił się cech aptekarzy, we Francji zaś w 1691 r. edyktem królewskim dochodzi do wydzielenia profesji chirurga z cechu balwierzy: zob. T. Gelfand, op. cit., s. 1125-1127; F. Lebrun, op. cit., s. $39-49$.

30 Ibid., s. 39.

31 Aptekarza, któremu pomimo sprzeciwu kolegium lekarskiego w 1704 r. Izba Lordów ostatecznie przyznała prawo do świadczenia porad lekarskich: T. Gelfand, op. cit., s. 1126.

32 Próby uzyskania większej niezależności cech chirurgów w Stuttgarcie bezskutecznie podejmował już w XVII w., ale w pierwszej połowie XVIII w. doszło do zaostrzenia sporu, w którym stronami był cech, rada miejska i Collegium medicum: zob. S. Sander, Handwerkschirurgen. Sozialgeschichte einer verdrängten Berufsgruppe, Göttingen 1989, s. 204-213.

33 L. Ghislaine, op. cit., s. 972-976. 
XVIII w., trwał praktycznie do końca stulecia ${ }^{34}$. Przyjmując jednak, że wspomniane zmiany w ostatnich dekadach epoki nowożytnej dotykały jedynie głównych ośrodków akademickich Zachodniej Europy, mając też na uwadze fakt pewnej inercji tego rodzaju procesów, należy założyć, że w odniesieniu do Rzeczypospolitej do końca jej istnienia funkcjonował model podziału oficjalnego lecznictwa według korporacyjnego schematu na medycynę uniwersytecką i cechową.

Podziały zauważalne w lecznictwie rzutowały oczywiście na system kształcenia, a co za tym idzie musiały mieć wpływ na zakres kompetencji i umiejętności nabywanych przez medyków, cyrulików i aptekarzy. W zależności od zmieniających się uwarunkowań prawnych i ścierania się interesów przedstawicieli różnych zawodów medycznych ulegał też zapewne ewolucji charakter edukacji i ramy kwalifikacji zdobywanych w trakcie nauki zawodu, nie ulega jednak wątpliwości, że były one inne w przypadku edukacji uniwersyteckiej i cechowej. Rozdział funkcji i podejmowanych czynności terapeutycznych w dawnym lecznictwie był więc prawdopodobnie także pochodną kompetencji posiadanych przez przedstawiciela danej profesji. Medyk stwierdzający konieczność wykonania zabiegu chirurgicznego częstokroć wzywał cyrulika. Wspominali o tym lekarze, np. Jacek Augustyn Łopacki35 oraz Bazyli Rudomicz: „poleciłem panu Andrzejowi Sajewiczowi otworzyć żyłę [mediana] lewego ramienia i upuścić około funta krwi"36. Felix Platter, będąc doktorem wykształconym na uniwersytecie, choć czasem wykonywał drobne zabiegi, korzystał z pomocy chirurga w bardziej skomplikowanych sytuacjach ${ }^{37}$. Rudomicz wspominał nawet o wspólnym z cyrulikiem prowadzeniu terapii podkomorzego bełskiego Marcina Brzezickiego: „razem z chirurgiem przez cały dzień leczyłem chorego" ${ }^{38}$, a także o scedowaniu przygotowania leków (prawdopodobnie) na aptekarza: „razem z tymże chirurgiem wyjechałem do Zamościa w celu wystarania się o leki" ${ }^{39}$. Z kolei braki w wiedzy z zakresu leków i roślin leczniczych u medyków ganił Marcin z Urzędowa. Narzekał on na lekarzy stwierdzając, że

nie tylko nie znają ziół, ale ani nie chcą się uczyć znać, ukazując swą nieumiejętność, że się pośmiewają z tych, którzy się takich rzeczy uczą; więc sami piszą do apteki takie rzeczy, których ani znają, ani rozumieją, a gdy ich pytasz, co by to było, niewiedzą co odpowiedzieć, jedno iż to jest w aptece ${ }^{40}$.

Być może narzekanie to było li tylko przejawem dumy autora, ale wydaje się, że faktycznie kompetencje lekarzy w zakresie znajomości ziół, leków oraz umiejętności ich wy-

34 T. Gelfand, op. cit., s. 1125-1131; F. Lebrun, op. cit., s. 41-46.

35 Z. Gajda, Jacek Augustyn Łopacki. Studia z dziejów kultury medycznej w Krakowie w XVIII w., Wrocław - Warszawa - Kraków 1969, s. 53.

36 B. Rudomicz, Efemeros czyli Diariusz prywatny pisany w Zamościu w latach 1656-1672 część druga 16641672, tłum. W. Froch, oprac. M.L. Klementowski, W. Froch, Lublin 2002, s. 241.

37 Pamiętnik Felixa Plattera nie pochodzi z terenów Rzeczypospolitej - praktykował on w XVI w. w Bazylei. W niniejszej pracy wykorzystany jest pomocniczo: F. Platter, Tagesbuch (Lebensbeschreibung) 1536-1567, oprac V. Lötscher, Basileae 1976, s. 435-436.

38 B. Rudomicz, Efemeros czyli Diariusz prywatny pisany w Zamościu w latach 1656 - 1672 część pierwsza 1656-1664, tłum. W. Froch, oprac. M.L. Klementowski, W. Froch, Lublin 2002, s. 205.

39 Ibidem.

40 M. z Urzędowa, Herbarz Polski To iest O Przyrodzeniu Zioł y Drzew Rozmaitych, Y Innych Rzeczy Do Lekarzy Należących [...], Kraków 1595, s. 40. Należy tu jednak nadmienić, że autor zielnika narzekał także na słabe kompetencje samych aptekarzy w zakresie znajomości ziół dodając: „Najdzie też i aptekarze i bardzo wiele doktorów, którzy mało ziół znają, na baby się spuszczają" (s. 40). 
twarzania mogły być niewystarczające. Chcąc zasięgnąć informacji o roślinach leczniczych spotykanych w ogrodzie, Jan III Sobieski wybrał się na spacer z aptekarzem, który objaśniał mu działanie napotykanych roślin ${ }^{41}$. Biorąc pod uwagę fakt częstej konkurencji i walki o uwagę i względy króla, która rozgrywała się na dworze pomiędzy rezydującymi tam lekarzami ${ }^{42}$, wybór konkretnej osoby do tego zadania raczej nie był dziełem przypadku. Z kolei Rudomicz, będąc medykiem, przepisywał pacjentom recepty na leki, które wykupić mieli w aptece. Sam też nie przygotowywał medykamentów, lecz zlecał wykonanie preparatów leczniczych aptekarzowi ${ }^{43}$. Po zakupieniu lokalnej apteki nie prowadził jej samemu, lecz zawarł odpowiednią umowę z aptekarzem:

Zawarłem następująca umowę z panem Stanisławem Brzeskim co do otworzenia apteki. Naszym nakładem zostanie przystosowana oficyna z całym wyposażeniem i surowcami, a on da swoją pracę, za co będzie otrzymywał trzecią część zysku, my zaś dwie trzecie za sklep, urządzenia i towary ${ }^{44}$.

Nie sposób jednoznacznie stwierdzić, czy przedstawiony podział funkcji między przedstawicieli różnych zaworów medycznych wynikał głównie z uwarunkowań prawnych, czy też z różnic kompetencyjnych. Biorąc jednak pod uwagę pojawiające się informacje wskazujące na łamanie monopoli korporacyjnych zarówno przez medyków, cyrulików, jak i aptekarzy, istotnym czynnikiem mogły być nie tylko przepisy, co także faktyczny brak kompetencji do podjęcia się danej czynności. W pewnych okolicznościach można bowiem napotkać sytuacje, w których medyk wykonywał proste zabiegi chirurgiczne („dał mu doktor wprzód syropku, po tym purgantia, po tym krew puścił"45), aptekarz udzielał porad i leczył pacjenta („do Kowna posłałem po aptekarza tamecznego Kwieczora, który mi krwi nie kazał puścić, ale mi głowę olejkami jakimiś smarował, która mię nie bolała, tylko szum w głowie cierpia$\nmid$ łem") $^{46}$, a cyrulik zalecał i dostarczał odpowiednie leki („,cyrulik z Bielska przyjechał przed południem samym, dał trunek paniej [...], proszek dał osobliwy ex mineralibus na dyzenterię, potem klistera aplikowana"47). Skrajnie lekceważącą postawą wobec teoretycznego podziału lecznictwa wykazywała się "doktorka” Regina Salomea z Rusieckich Pilsztynowa ${ }^{48}$. Wydaje się, że nie mając żadnych formalnych kompetencji (tytuł doktorki nadała sobie sama), podejmowała się każdego zadania, które postrzegała jako będące w zasięgu jej możliwości. Parała się przepisywaniem, ale też sprzedawaniem leków, chirurgią okulistyczną, położnic-

41 K. Sarnecki, Pamiętniki z czasów Jana Sobieskiego, oprac. J. Woliński, Wrocław 2004, s. 203.

42 O konfliktach pomiędzy lekarzami Władysława IV Wazy (Jana Kaspera Kraffta oraz Andrzeja Knöeffela) pisali Albrycht Stanisław Radziwiłł oraz Maciej Vorbek Lettow (A.S. Radziwiłł, Pamiętnik o dziejach w Polsce. Tom 2, 16371646, tłum. i oprac. A. Przyboś, R. Żelewski, Warszawa 1980, s. 290; M. Vorbek-Lettow, Skarbnica pamięci, oprac. E. Galos, F. Mincer, Wrocław - Warszawa 2006, s. 179), z kolei spór sprawujących opiekę nad Stefanem Batorym lekarzy Mikołaja Bucellego i Szymona Simoniusa doczekał się drukowanej polemiki (N. Buccella, Confutatio responsi Simonis Simonii Lucensis ad epistolam Georgii Chiakor [...] de morte Stephani I Poloniae regis, Kraków 1558).

43 B. Rudomicz, Efemeros [...] część pierwsza, s. 98, 256.

44 Decyzja o zleceniu prowadzenia apteki była zapewne podyktowana wieloma czynnikami, wydaje się jednak, że kwestia kwalifikacji mogła także mieć istotne znaczenie: B. Rudomicz, Efemeros [...] część druga, s. 147.

45 K. Opaliński, Listy Krzysztofa Opalińskiego do brata Łukasza 1641-1653, red. R. Pollak, Wrocław 1957, s. 97.

46 M. Matuszewicz, Diariusz życia mego. Tom 1, 1714-1757, oprac. B. Królikowski, Warszawa 1986, s. 113.

47 J.A. Chrapowicki, Diariusz. Część pierwsza: lata 1656-1664, oprac. T. Wasilewski, Warszawa 1978, s. 206.

48 Część z opisywanych przez nią przypadków terapii miała miejsce na terytorium innych państw, w tym Imperium Osmańskiego. Jednak w relacjach z terenów Rzeczypospolitej nie daje się zauważyć zmiany jej postawy, nie była ona zatem wynikiem jedynie odmiennych realiów prawnych. 
twem, leczeniem chorób skór oraz chorób wewnętrznych ${ }^{49}$. Natomiast w przypadku potrzeby upuszczenia krwi zleciła wykonanie tej czynności komu innemu ${ }^{50}$. Jest to o tyle istotne, że odnotowywała kilkukrotnie fakt podejmowania się chirurgicznych zabiegów okulistycznych. Wydaje się zatem, że jej decyzje nie były podyktowane chęcią respektowania prawa cechowego, lecz raczej wynikały z posiadanych umiejętności w dziedzinie okulistyki i braku takowych w odniesieniu do przeprowadzania upustów krwi.

Na codzienną praktykę i podejmowane przez różnych przedstawicieli zawodów medycznych działania miały wpływ nie tylko obowiązujące przepisy czy też system kształcenia, lecz także sposób postrzegania tych zawodów w społeczeństwie, koszt ich usług oraz ogólna dostępność. Percepcja zawodów medycznych w dawnym społeczeństwie była częściowo powiązana z charakterem wykonywanych zabiegów, jednocześnie jednak była skorelowana z ceną usług i statusem ekonomicznym terapeuty. Czynniki te pośrednio były współzależne: do pewnego stopnia prestiż lekarza decydował o wysokości pobieranych przez niego honorariów, a co za tym idzie - jego statusie ekonomicznym. Z kolei znaczna zamożność samorzutnie przekładała się na większy autorytet lekarza, a jednocześnie też na większe zaufanie do jego zaleceń. Wobec niewielkiej skuteczności nowożytnych metod terapeutycznych ${ }^{51}$ kwestia zaufania do terapii mogła być kluczowa w subiektywnym odczuwaniu poprawy przez pacjenta. W dużym stopniu zatem czynnik zamożności (i ceny usług) wpływał na ich skuteczność, co z kolei podnosiło popularność terapeuty i jego prestiż, które finalnie decydowały o zarobkach i statusie ekonomicznym lekarza. Te współzależne powiązania obserwować można choćby w relacjach dotyczących zarobków, zamożności i prestiżu zapisanych przez Pilsztynową czy Macieja Vorbek-Lettowa ${ }^{52}$. Oprócz teoretycznego rozdziału funkcji pomiędzy przedstawicieli różnych zawodów lekarskich pozostawała także kwestia świadomego podejmowania (lub też zaniechania) pewnych czynności i działań terapeutycznych uważanych za bardziej lub mniej prestiżowe. Takie „rozwarstwienie” przebiegające w poprzek rozdziałów wynikających z prawnych kwalifikacji wydaje się w kontekście funkcjonowania nowożytnego społeczeństwa dość prawdopodobne. Niemniej źródła nie potwierdzają jednoznacznie samoograniczania się terapeutów do bardziej prestiżowych działań w miarę wzrostu ich reputacji. Relacje Rudomicza dotyczące pobieranych przez niego zarobków wskazują, że przez cały okres kariery lekarskiej przyjmował drobniejsze wynagrodzenia, prawdopodobnie za proste porady i pomoc medyczną ${ }^{53}$. Podobne zachowania można odnaleźć w notatkach Plattera: w miarę zyskiwania coraz lepszej reputacji leczył nawet bardzo zamożnych i wpływowych pacjentów, osiągając przy tym wysokie honoraria. Nawet wówczas nie przestał jednak podejmować się terapii uciążliwych ${ }^{54}$ lub nierokujących

49 R.S. z Rusieckich Pilsztynowa, Proceder podróży i życia mego awantur, oprac. Roman Pollak, Kraków 1957, s. $43,44,56,93,172$.

50 Pilsztynowa w odniesieniu do prowadzonych terapii zawsze wyraża się w pierwszej osobie, opisując zaś upust krwi używa sformułowania: „kazałam jej krew puścić z ręki”; ibid., s. 230.

51 Realna skuteczność ówczesnych metod terapeutycznych jest nadal przedmiotem badań i trudno jednoznacznie ją ocenić. Nawet jednak bez pogłębionych analiz można z całą pewnością stwierdzić, że ówczesna medycyna w wielu schorzeniach i dolegliwościach nie potrafiła znacząco pomóc chorym.

52 O funkcjonowaniu zapętlonej triady zaufania, skuteczności i bogactwa zob. J. Węglorz, Zdrowie, choroba, s. $250-254$.

53 Ibid., s. 245-249.

54 Za uciążliwe uznaje się tu przypadki, gdy musiał odbywać dalekie podróże w celu odwiedzenia pacjenta, spędzać w niekomfortowych warunkach nawet kilka dni przy łóżku chorego czy też wyruszać w drogę w trudnych warunkach atmosferycznych (np. śnieżyca). Przeważanie nie wiązało się to z rekompensatą finansową, można 
sukcesu, nieraz leczył także ludzi o znacznie niższym statusie ekonomicznym, otrzymując w zamian skromne wynagrodzenie ${ }^{55}$. Trudno określić, czy taka postawa była charakterystyczna dla wszystkich przedstawicieli profesji medyka. Niestety przeprowadzone badania nie uprawniają do szerszych uogólnień w tym zakresie, dotyczą bowiem jedynie pojedynczych przypadków lekarzy, który odnotowywali wystarczająco szczegółowo informacje odnośnie specyfiki swojej pracy.

Niebagatelny wpływ na podejmowanie lub omijanie niektórych praktyk terapeutycznych przez przedstawicieli zawodów medycznych miała także ogólnospołeczna opinia na ich temat. Wyrażane w źródłach nieprzychylne poglądy odnoszące się np. do chirurgii czy położnictwa jako mniej prestiżowych zajęć mogły skuteczniej niż ewentualne formalne zakazy ograniczyć zainteresowanie tymi gałęziami medycyny ze strony uniwersyteckich medyków. Jeszcze w XVIII w. Ludwik Perzyna narzekał na niechęć mężczyzn do podejmowania zawodu akuszera, ganiąc przy tym: „Niemaią się czego wstydzić nasi Polacy, [uważający - J.W.] odbieranie dzieci, za nienależącą robotę do męszczyzn" ${ }^{\prime 56}$. Profesja medyka otoczona była powagą i wiązała się ze znacznym prestiżem, ale i koszt studiów uniwersyteckich był niebagatelny, stąd też był to zawód wybierany czasem przez przedstawicieli stanu szlacheckiego. Zajmowanie się operacjami chirurgicznymi uznawali oni nieraz za niegodne swojego statusu i uwłaczające szlachcicowi. Ponadto ówczesna chirurgia była brutalna przez brak skutecznych środków znieczulających, co u niektórych praktykujących cyrulików mogło wywoływać duży stres wynikający z konieczności zadawania bólu i cierpienia bliźnim. Wspomniany już Plater odnotował przypadek swojego szwagra, Franza Jäckelmanna, który będąc chirurgiem litotomistą, cierpiał z powodu wykonywanego zawodu na melancholię i miał oświadczył, że „nie chce więcej być mordercą"57. Materiał źródłowy nie pozwala niestety jednoznacznie ocenić, czy negatywna opinia o specyfice niektórych specjalności chirurgicznych była czynnikiem w istotny sposób ograniczającym podejmowanie tej profesji. Pojawiające się jednak niechętne sądy związane z okrucieństwem i krwawym charakterem ówczesnej chirurgii uprawdopodobniają taką możliwość.

Zagadnienie rozdziału kompetencji pomiędzy przedstawicielami dawnych zawodów medycznych nie daje się jednoznacznie i bezspornie uporządkować na gruncie obowiązujących przepisów czy też konsekwencji przyjętego systemu kształcenia. Przynależność do określonej grupy zawodowej (np. medyków, cyrulików czy aptekarzy) nie wiązała się bezwzględnie z podejmowaniem się jedynie działań terapeutycznych przypisanych do tej grupy. Nie oznaczała także automatycznie braku kwalifikacji w zakresie innych niż charakterystyczne dla danej korporacji metod leczenia, choć wydaje się, że była to sytuacja stosunkowo częsta. W praktyce leczniczej przedstawiciele różnych zawodów medycznych niejednokrotnie podejmowali się terapii, które powinny być realizowane przez reprezentantów innej korporacji. Powodowało to czasem powstawanie sporów kompetencyjnych,

więc uznać te przypadki świadczenia usług lekarskich za mniej atrakcyjne: zob. F. Platter, op. cit., s. 357, 369, $383,390,446,449$.

55 Ibid., s. 533-536.

56 L. Perzyna, Nauka połozna krotko zebrana. Cyrulikom położnym, iako też i Babom, czyli Kobietom, przy rozwiązaniu rodzących Położnic służącym dla wiadomości bardzo potrzebna [...], Kalisz 1790, k. nlb. 4.

57 Choć Platter opisywał sytuację mającą miejsce w zupełnie innych realiach, niż te znane z Rzeczypospolitej, wydaje się, że fakt odczuwania dyskomfortu psychicznego związanego z trudną pracą chirurga dotykać mógł wszystkich przedstawicieli tej profesji, niezależnie od miejsca: F. Platter, op. cit., s. 438 (tłumaczenie własne). 
które bywało, że kończyły się procesem sądowym. Choć podejmowano w nich wątek posiadania praktycznych kompetencji (lub ich braku) przez określonego lekarza, to był to raczej zabieg retoryczny, mający potwierdzić słuszność wnoszącej oskarżenie strony. Przedmiotem procesu było nie tyle wykazanie błędu czy niekompetencji, lecz przede wszystkim udowodnienie prawa danej korporacji do prowadzenia określonych praktyk terapeutycznych i wykazanie łamania uznanego monopolu przez oskarżanego terapeutę ${ }^{58}$. Sytuacja taka w pewnym stopniu potwierdza przedstawioną powyżej tezę, że przynależność do danego zawodu medycznego wiązała się z formalnym prawem wykonywania określonych działań terapeutycznych, ale jednocześnie nie ograniczała w praktyce aktywności na innych polach, o ile dany lekarz posiadał umiejętności i wiedzę z ich zakresu.

Materiał źródłowy niejednokrotnie nie pozwala z całkowitą pewnością ustalić, kto wykonywał dany zabieg terapeutyczny. Częstokroć nawet w sytuacji, w której autor wzmiankuje korzystanie z usługi medyka czy też cyrulika lub aptekarza, nie stwierdza jednoznacznie, że opisany proces leczenia został w całości przeprowadzony przez tego terapeutę. Problem taki pojawia się czasem w przypadku zabiegu flebotomii, co może sugerować, że za sformułowaniem zalecenia i rzeczywistym wykonaniem zabiegu mogła nie stać ta sama osoba. W odniesieniu do notatek dotyczących upustów krwi zdarza się bowiem, że opisują one wizytę konkretnego lekarza, ale w sposób niejednoznaczny informują o samej wykonanej czynności, pozostawiając pewne niedopowiedzenie. W tego rodzaju zapiskach można odnieść wrażenie, że choć zalecenie wydał wymieniony terapeuta, to sam zabieg nie koniecznie był przez niego osobiście wykonany: „był pan Gabryjel cyrulik i odjechał [...] puszczono mi krew z obu żył krzyżowych u nóg obu”59 „ „u Orłowskiego, sławnego i barzo wielkiej eksperiencji doktora, [...] Kazał mi tedy hemoroidy otworzyć"60, „doktorowie [...] kazali mi nazajutrz krew puścić z ręki i na laksę dali"61 , „doktor Braum (upra)gnion był u mnie przed południem i dysponował ad curationem należało. Po południu o szóstej krew mi puszczono z medyjany"62.

Pomimo zawiłej sytuacji prawnej i nagminnego występowania sytuacji niejednoznacznych, a nawet stojących w sprzeczności do teoretycznie przyjętych norm, w odniesieniu do pewnych okoliczności daje się wskazać na występowanie powtarzalnych schematów postępowania i zwyczajowo przyjętych rozwiązań. Codzienna praktyka lecznicza ukazana w egodokumentach epoki staropolskiej pozwala stwierdzić, że sprawy związane z urazami mechanicznymi, takimi jak złamania, stłuczenia, rany cięte czy postrzałowe, praktycznie zawsze była domeną działania cyrulików. Zarówno pamiętniki, jak i korespondencja ukazują stosunkowo dużo sytuacji, w których doszło do nieszczęśliwych wypadków, upadków z konia czy też obrażeń w walce. Bardzo często źródła nie wskazują sposobu leczenia i nie specyfikują, jaki konkretnie terapeuta podjął się zadania. W sytuacjach jednak, gdy taka informacja zostaje podana, w zdecydowanej większości wzmiankuje się pomoc cyrulika. Przypadki leczonych przez chirurgów ran odniesionych w walce (zarówno postrzałowych,

58 K. Pękacka-Falkowska, Spory kompetencyjne między łaziebnikami i chirurgami toruńskimi w XVIII w. Przypadek Johanna Zandera, „Medycyna Nowożytna” t. 21, 2015, nr 2, s. 137-171; J. Węglorz, Znaczenie i postrzeganie kwalifikacji, s. 57.

59 J.A. Chrapowicki, Diariusz. Część druga: lata 1665-1669, oprac. A. Rachuba, T. Wasilewski, Warszawa 1988 , s. 80.

60 M. Matuszewicz, op. cit., s. 113

61 J. Charkiewicz, Dyjariusz podróży hiszpańskiej z Wilna do miasta Walencyi, oprac. B. Rok, Wrocław 1998, s. $168-169$.

62 J.A. Chrapowicki, Diariusz. Część pierwsza, s. 245. 
jak i od broni białej) wspominali Marcin Matuszewicz ${ }^{63}$, Michał Obuchowicz ${ }^{64}$ i Jan Chryzostom Pasek ${ }^{65}$. W gestii kompetencji chirurgów pozostawało także przeprowadzanie bardziej lub mniej poważnych operacji, w tym amputacji kończyn po poważnych urazach ${ }^{66}$. W staropolskich źródłach znaleźć można także wzmianki o opatrywaniu przez cyrulików ran, zszywaniu skóry oraz opatrywaniu stłuczeń67, czasem także o pomocy udzielonej po niebezpiecznych wypadkach przez balwierza, jak to zdarzyło się synowi Zbigniewa Ossolińskiego:

biegając po wschodach i gankach złych i z starości pogniłych, spadł z wysoka prawie na głowę, tylko że się rękami zasłonił. Łaska pana Boga dobrotliwego, że której ręki nie złamał z tak srogiego spadnienia i głowy nie zajął; przypłacił jednak tego bólmi wielkimi w rękach, do których wpadły były puchliny i z ogniem wielkim, tandem a to go ratował balwierz z Kazimierza ${ }^{68}$.

W razie wystąpienia urazów związanych ze stłuczeniami, upadkami i przypadków „Wzburzenia krwi” (czyli wypadków także o charakterze emocjonalnym) bardzo często stosowano upusty krwi, które miały uspokoić wzburzone humory i zabezpieczyć przez poważniejszymi konsekwencjami zaburzenia ich równowagi69. Zabieg krwiopustów teoretycznie powinien być wykonywany właśnie przez cyrulika, co także sugeruje tę grupę zawodową jako właściwą do leczenia urazów ${ }^{70}$. Choć niektóre z opisywanych w źródłach wypadków sprawiają wrażenie bardzo poważnych, nawet wówczas zdarzały się sytuacje, w których skutecznej pomocy udzielał empiryk bez formalnego wykształcenia. O imponującej i bardzo fachowej interwencji medycznej uzyskanej od cyrulika żydowskiego wspominał Bartłomiej Pstrokoński¹ ${ }^{1}$ W trakcie upadku z powozu doznał on otwartego złamania podudzia („bom nogę lewą nad samą kostką złamał”), pomimo krwotoku i wystających kości, które przebiły jego buty, lokalny felczer zdołał „bez wszelkiego bólu i łagodnie” nastawić złamanie i doprowadzić pacjenta do zdrowia:

układa kości połamane, porozchodzone, tak, że jakby w jakim worku strząsnione, klękotały; wsadza w łupki nogę i tak z łaski Boskiej robi wszystko doskonale, że temu pierwszemu opatrzeniu ocalenie tej nogi przyznaję $e^{72}$.

Pstrokoński zanotował, że następnego dnia został przewieziony wozem do pobliskiego dworu, skąd po dwóch tygodniach przetransportowano go dalej, a po kolejnych kilku

63 M. Matuszewicz, op. cit., s. 301, 411.

64 F., M., i T. Obuchowicze, Pamiętniki Filipa, Michała i Teodora Obuchowiczów (1630-1707), oprac. H. Lulewicz, A. Rachuba, Warszawa 2003, s. 288.

65 J. Ch. Pasek, Pamiętniki, oprac. W. Czapliński, Wrocław 2003, s. 123, 558.

66 Ibid., s. 558; K. Sarnecki, op. cit., s. 53.

67 J.A. Chrapowicki, Diariusz. Część druga, s. 80-81, 525; J. Ossoliński, Pamiętnik (1595-1621), oprac. J. Kolasa, J. Maciszewski, red. W. Czapliński, Wrocław 2004, s. 25-26; J. Ch. Pasek, op. cit., s. 441.

68 Z. Ossoliński, Pamiętniki Zbigniewa Ossolińskiego wojewody sandomierskiego, wyd. W. Kętrzyński, Lwów 1879 , s. $57-58$

69 J. Węglorz, Zdrowie, choroba, s. 153-154.

70 Ibid., s. 135-161. Faktyczne zachowania medyczne zobrazowane w egodokumentach nie potwierdzają jednoznacznego zaszeregowania krwiopustów jako przeznaczonych do wykonywania wyłącznie przez cechowych chirurgów, co szerzej omówiono w dalszej części tekstu.

71 B. Pstrokoński, Pamiętnik księdza Pstrokońskiego kanonika katedralnego gnieźnieńskiego, oprac. E. Raczyński, Wrocław 1844, s. 31-32.

72 lbid. 
tygodniach, wedle słów autora, był już zdrowy ${ }^{73}$. Wypadek miał miejsce 29 maja 1755 r., a w 1756 r. i kolejnych latach autor podejmował wiele obowiązków i podróży nigdy nie wzmiankując jakichkolwiek trudności w poruszania czy kłopotów z nogą (co więcej, w 1768 r. udał się w bardzo długą i wyczerpującą podróż do Włoch). Prowadzony tryb życia oraz brak notatek świadczących o konsekwencjach, które mogłyby być związane z wypadkiem, świadczą o niebywałych kwalifikacjach felczera, który zdołał uratować pacjenta po tak poważnym urazie.

O ile w przypadku urazów i ran w przeważającej mierze zwracano się o pomoc do cyrulików, to w zakresie popularnych działań leczniczych i profilaktycznych trudno wykazać obecność powtarzalnych prawidłowości i istotnych ograniczeń. Wśród najczęściej występujących zabiegów, takich jak przeczyszczenia, lewatywy, stawianie baniek, stosowanie plastrów i okładów, czy nawet upuszczanie krwi, wybór terapeuty wydaje się w niewielkim stopniu zależny od teoretycznych podziałów kompetencyjnych ${ }^{74}$. Nawet flebotomia, którą przeważnie przeprowadzał cyrulik bywała wykonywana także przez medyków: „dał mu doktor wprzód syropku, po tym purgantia, po tym krew puścił"75. Z analizy omawianych źródeł wynika, że w codziennej praktyce medycznej zabiegi te były stosowane zarówno przez medyków jak cyrulików i aptekarzy, a czasem także przez osoby nieposiadające formalnych kwalifikacji, a jedynie przyuczone do ich przeprowadzania. Jakubowi Lanhausowi w czasie pobytu w Rzymie goszczący go zakonnicy duchacy zaproponowali, aby zamiast korzystać z usługi cyrulika upuścił krew w ich klasztorze: „bo ich kamerdyner umie dobrze i puszczał wszystkim"76. Także wzmianki o stosowaniu flebotomii, w których autor sam decyduje o przeprowadzeniu zabiegu, niewspominając o wizycie lekarza, mogą być świadectwem wykonania terapii przez kogoś z otoczenia pacjenta: „powróciwszy do Ołyki, po zażyciu lekarstwa, kazałem sobie lancetem puszczać zepsutą krew z żyły"77. O zastosowaniu środków przeczyszczających i lewatyw w sposób sugerujący autoterapię notował wielokrotnie Jan Antoni Chrapowicki: „pulverum puniceum brałem rano, w wieczór klisterkę wolną"78, „późno klisterę wziąłem”79, „zażyłem lekkiej klistery z dobrym skutkiem"80, „jam barzo chory, brałem klisterkę piwną"81. Tego rodzaju niejednoznaczne notatki oczywiście nie upoważniają do budowania kategorycznych twierdzeń, wydają się jednak uprawdopodabniać fakt wykonywania prostych zabiegów medycznych także przez przyuczonych do tego domowników. Za możliwością świadczenia nieprofesjonalnego lecznictwa także przez osoby nieposiadające formalnego wykształcenia i niebę-

73 Ibid., s. 33: „kładą mnie na wóz cierniem wyłożony i piernatami, żebym się nie strząsł, i składają w Lipym, we dworze, gdzie byłem bez wszelkiego bólu i łagodnie opatrowny od wspomnionego żydka, a po wzmocnieniu nogi, w niedziel dwie, przybyli z Chocza ludzie, i na wielkiem łóżku przenieśli mię rękami swemi do Chocza, gdzie w pare tygodni wyzdrowiałem".

74 Pomimo istnienia monopoli cechowych, przypisujących prawo wykonywania pewnych zabiegów przedstawicielom określonych zawodów medycznych, trudno jest wykazać ich przestrzegania w codziennej praktyce na terenie Rzeczypospolitej; zob. F. Lebrun, op. cit., s. 62-67.

75 K. Opaliński, op. cit., s. 97

76 Achiwum Arcybiskupstwa w Gnieźnie, rkps 227, J. Lanhaus, Itinerarium R.P. Canonici Ordinis Custodum SS. Sepulchri, s. 308.

77 A.S. Radziwiłł, Pamiętnik o dziejach w Polsce. Tom 1, 1632-1636, tłum. i oprac. A. Przyboś, R. Żelewski, Warszawa 1980, s. 377.

78 J.A. Chrapowicki, Diariusz. Część pierwsza, s. 245.

79 Ibid.

80 Ibid., s. 391.

81 Ibid., s. 395. 
dące członkami żadnej z korporacji przemawiać może również fakt pojawiania się druków o tematyce medycznej w indywidualnych księgozbiorach mieszczańskich ${ }^{82}$.

Podsumowując, należy stwierdzić, że funkcjonowanie w praktyce formalnego podziału lecznictwa i rozgraniczenia zakresu działalności terapeutycznej miało raczej charakter płynny i umowny. Z wyjątkiem prawa cechowego, które regulowało zasady konkurencji, pozostałe obostrzenia i podziały były niedookreślone. Jednak nawet monopol cechowy nie był restrykcyjnie przestrzegany, a źródła dostarczają licznych przykładów jego naruszania. Co istotne, chorzy nie wykazywali zdecydowanych i jednoznacznych schematów postępowania w zakresie doboru terapeuty. Licznie występują wzmianki świadczące o tym, że w porównywalnych sytuacjach leczenia podejmowali się przedstawiciele różnych profesji lekarskich. Wydaje się, że pomimo istnienia prawnych i kompetencyjnych podziałów w zasadniczej mierze o wyborze terapeuty decydowała jego dostępność oraz osobiste kwalifikacje do przeprowadzenia leczenia (niekoniecznie wynikające z przynależności do określonej korporacji medycznej). Do wyraźnego rozgraniczenia zakresu działań dochodziło natomiast, gdy kilku terapeutów jednocześnie prowadziło leczenie lub gdy osobiste kwalifikacje danego lekarze nie pozwalały mu na przeprowadzenie kuracji i wymuszały wezwanie pomocy.

\section{Bibliografia}

\section{Źródła}

Achiwum Arcybiskupstwa w Gnieźnie, rkps 227, J. Lanhaus, Itinerarium R.P. Canonici Ordinis Custodum SS. Sepulchri.

Buccella N., Confutatio responsi Simonis Simonii Lucensis ad epistolam Georgii Chiakor [...] de morte Stephani I Poloniae regis, Kraków 1558.

Charkiewicz J., Dyjariusz podróży hiszpańskiej z Wilna do miasta Walencyi, oprac. B. Rok, Wrocław 1998.

Chrapowicki J.A., Diariusz. Część druga: lata 1665-1669, oprac. A. Rachuba, T. Wasilewski, Warszawa 1988.

Chrapowicki J.A., Diariusz. Część pierwsza: lata 1656-1664, oprac. T. Wasilewski, Warszawa 1978.

Matuszewicz M., Diariusz życia mego. Tom 1, 1714-1757, oprac. B. Królikowski, Warszawa 1986.

Obuchowicze F., M., i T., Pamiętniki Filipa, Michała i Teodora Obuchowiczów (1630-1707), oprac. H. Lulewicz, A. Rachuba, Warszawa 2003.

Opaliński K., Listy Krzysztofa Opalińskiego do brata Łukasza 1641-1653, red. R. Pollak, Wrocław 1957.

Ossoliński J., Pamiętnik (1595-1621), oprac. J. Kolasa, J. Maciszewski, red. W. Czapliński, Wrocław 2004.

Ossoliński Z., Pamiętniki Zbigniewa Ossolińskiego wojewody sandomierskiego, wyd. W. Kętrzyński, Lwów 1879. medycyny i higieny w Rzeczpospolitej XVI-XVIII wieku, red. A. Karpiński, Warszawa 2009, s. 194-195. 
Pasek J.Ch., Pamiętniki, oprac. W. Czapliński, Wrocław 2003.

Perzyna L., Nauka połozna krotko zebrana. Cyrulikom położnym, iako też i Babom, czyli Kobietom, przy rozwiązaniu rodzących Położnic służącym dla wiadomości bardzo potrzebna. [...], Kalisz 1790.

Pilsztynowa z Rusickich R.S., Proceder podróży i życia mego awantur, oprac. R. Pollak, Kraków 1957.

Platter F., Tagesbuch (Lebensbeschreibung) 1536-1567, oprac. V. Lötscher, Basileae 1976.

Pstrokoński B., Pamiętnik księdza Pstrokońskiego kanonika katedralnego gnieźnieńskiego, oprac. E. Raczyński, Wrocław 1844.

Radziwiłł A.S., Pamiętnik o dziejach w Polsce. Tom 1, 1632-1636, tłum. i oprac. A. Przyboś, R. Żelewski, Warszawa 1980.

Radziwiłł A.S., Pamiętnik o dziejach w Polsce. Tom 2, 1637-1646, tłum. i oprac. A. Przyboś, R. Żelewski, Warszawa 1980.

Rudomicz B., Efemeros czyli Diariusz prywatny pisany w Zamościu w latach 1656-1672 część druga 1664-1672, tłum. W. Froch, oprac. M.L. Klementowski, W. Froch, Lublin 2002.

Rudomicz B., Efemeros czyli Diariusz prywatny pisany w Zamościu w latach 1656-1672 część pierwsza 1656-1664, tłum. W. Froch, oprac. M.L. Klementowski, W. Froch, Lublin 2002.

Sarnecki K., Pamiętniki z czasów Jana Sobieskiego, oprac. J. Woliński, Wrocław 2004.

Urzędowa M. z, Herbarz Polski To iest O Przyrodzeniu Zioł y Drzew Rozmaitych, Y Innych Rzeczy Do Lekarzy Należących [...], Kraków 1595.

Vorbek-Lettow M., Skarbnica pamięci, oprac. E. Galos, F. Mincer, Wrocław - Warszawa 2006.

\section{Literatura przedmiotu}

Bąkowski-Kois D., Historia mentalności epoki nowożytnej. Jeszcze o problemach, „Historyka. Studia Metodologiczne" t. 31, 2001, s. 91-100.

Brzeziński T., Kształtowanie się zawodu lekarza i koncepcje kształcenia, [w:] Historia medycyny, red. idem, Warszawa 1988, s. 52-79.

Burnby J., An Examined and Free Apothecary, [w:] The History of Medical Education in Britain, red. V. Nutton, R. Porter, Amsterdam - Atlanta 1995, s. 16-36, DOI 10.1163/9789004418394_004.

Companion Encyclopedia of the History of Medicine, red. W.F. Bynum, R. Porter, t. 2, London - New York 1993.

Gajda Z., Jacek Augustyn Łopacki. Studia z dziejów kultury medycznej w Krakowie w XVIII w., Wrocław - Warszawa - Kraków 1969.

Jagla J., Boska medycyna i niebiescy uzdrowiciele wobec kalectwa i chorób człowieka, Warszawa 2004.

Lebrun F., Jak dawniej leczono, Lekarze, święci i czarodzieje w XVII i XVIII wieku, tłum. Z. Podgórska-Klawe, Warszawa 1997.

Nowosielska E., Szkorbut w Rzeczypospolitej XVII i XVIII wieku, [w:] Wśród córek eskulapa. Szkice z dziejów medycyny i higieny w Rzeczpospolitej XVI-XVIII wieku, red. A. Karpiński, Warszawa 2009, s. 185-231.

Pękacka-Falkowska K., Spory kompetencyjne między łaziebnikami i chirurgami toruńskimi w XVIII w. Przypadek Johanna Zandera, „Medycyna Nowożytna” t. 21, 2015, nr 2, s. $137-171$. 
Puschmann T., A History of Medical Education. From the Most Remote to the Most Recent Times, tłum. i red. Evan H. Hare, London 1891.

Rembieliński R., Kuźnicka B., Historia farmacji, Warszawa 1972.

Rolnik D., Portret szlachty czasów stanisławowskich, epoki kryzysu, odrodzenia i upadku Rzeczypospolitej w pamiętnikach polskich, Katowice 2009.

Sander S., Handwerkschirurgen. Sozialgeschichte einer verdrängten Berufsgruppe, Göttingen 1989.

Szulakiewicz W., Ego-dokumenty i ich znaczenie w badaniach naukowych, „Przegląd Badań Edukacyjnych" t. 1 (16), 2013, s. 65-84, DOI 10.12775/pbe.2013.006.

Talbot Ch.H., Medicine in Medieval England, London 1976.

Topolski J., Teoria wiedzy historycznej, Poznań 1983.

Wear A., Explorations in Renaissance Writings on the Practice of Medicine, [w:] The Medical Renaissance of the Sixteenth Century, red. A. Wear, R.K. French, I.M. Lonie, Cambridge 1985, s. 118-145.

Węglorz J., Zdrowie, choroba i lecznictwo w społeczeństwie Rzeczypospolitej XVI-XVIII wieku, Toruń 2015.

Węglorz J., Znaczenie i postrzeganie kwalifikacji do uprawiania sztuki lekarskiej w Rzeczypospolitej, [w:] Sapientia ars vivendi putanda est. Wokół kultury i polityki. Studia z dziejów nowożytnych ofiarowane Profesorowi Marianowi Chachajowi, red. A. Perłakowski, B. Rok, F. Wolański, Kraków 2019, s. 47-60.

\section{Finansowanie}

Tekst prezentuje rezultaty badań finansowanych z grantu Narodowego Centrum Nauki 2017/26/E/HS3/00452.

Jakub Węglorz, dr nauk historycznych, adiunkt w Zakładzie Historii Polski i Powszechnej XVI-XVIII w. w Instytucie Historycznym Wydziału Nauk Historycznych i Pedagogicznych Uniwersytetu Wrocławskiego. Główne pola badawcze: historia mentalności epoki staropolskiej, dawne metody leczenia oraz medycyna nowożytna.

e-mail: jakub.weglorz@uwr.edu.pl

Data zgłoszenia artykułu: 13 grudnia 2020

Data przyjęcia do druku: 29 stycznia 2021 